УДК 342.5.071

DOI

\author{
A. А. Настюк \\ orcid.org/0000-0002-2014-1084 \\ кандидат юридичних наук, доцент, \\ доцент кафедри конституційного адміністративного та фінансового права \\ Академії праці, соціальних відносин і туризму
}

C. М. Третяк

orcid.org/0000-0001-5932-7487

старший викладач кафедри конституційного адміністративного та фінансового права

Академії праці, соціальних відносин і туризму

\title{
СИСТЕМА ЗБОРУ ДАНИНИ ДО ПРАВЛІННЯ СВЯТОСЛАВА ІГОРОВИЧА
}

Постановка проблеми. Натепер в Україні продовжується процес розвитку податкової системи України. У такому процесі головне - зберегти баланс між потребами держави й платниками податків. Для вдосконалення сучасної системи збору податків слід розкрити аспекти її виникнення та розвитку, щоб зрозуміти природу й з'ясувати динаміку ї̈ розвитку. Нині ми намагаємося перейняти найкращий світовий досвід, але розвиток кожної національної податкової системи мав свої особливості й спирався на національні правові традиції. Щоб ефективно здійснювати в майбутньому фіскальну політику, ми маємо максимально дослідити специфічні аспекти формування та функціонування механізмів накопичення ресурсної бази шляхом сплати податків. Також маємо врахувати соціокультурні аспекти руського суспільства, розглянути нові погляди на актуальні питання проблематики сплати данини та їі механізми проведення. Слід виробити нові підходи до вивчення предмету нашого дослідження. Думка про примітивність і неефективність системи збору данини не відповідає тим викликам і проблемам, які розв'язувала Київська Русь у досліджуваний нами період. Русь активно боролась за сфери розширення свого впливу над сусідами, намагалась взяти під контроль основні торговельні шляхи східної Європи й виконувала інші важливі стратегічні задачі. Для досягнення поставлених цілей Русь мала володіти ефективною системою оподаткування підлеглих суб'єктів.

Стан дослідження. Розкриттям проблемних питань дослідження системи збирання данини в Київській Русі займався цілий ряд науковців: П.П. Толочко, І.Я. Фроянов, С.В. Юшков, М.Н. Тихоміров, М.Ю. Брайчевський, М.Б. Свердлов, П.В. Цимбал, М.Н. Шевердін, Е.С. Бондаренко, К.С. Айсханова, Ю.М. Походзіло, Ф.О.Ярошенко,Р.Конта,С.В.Кудін,Я.В.Журавль та інші. Однак і нині система збору данини на початкових етапах розвитку Київської Русі не досліджена повною мірою. Причиною неможливості iї повного розкриття є недостатність джерельної бази. Навіть ті джерела, які дійшли до нас, іноді суперечать один одному.

Метою статті $є$ дослідження аспектів щодо тенденцій розвитку системи збору податків до князювання Святослава Ігоровича.

Виклад основного матеріалу. Розглянемо, яка система збору данини діяла на Русі до Рюрика, а саме тоді, коли руси ділились на куявців, арсанців, славів. Про такий розподіл русів нам повідомляють арабські джерела [1. с, 34].

Араби, вказуючи відомості про русів, торкнулися питання сплати податків. Гардізі у своїй роботі «Зайн ал-ахбар» (Краса розповідей) повідомив про те, що царю русів сплачують десять процентів із торговельних операцій [2, с. 48].

Автор також вказує на те, що руси не мають нерухомості. Батьки русів передавали своїм хлопчикам тільки меч і промовляли: «У мене немає ні золота, ні срібла, ні скота, щоб залишити тобі в спадок, сам собі все добудь мечем». Гардізі наголошував: «У них немає ні посівів, ні пашен. І вони користуються зазвичай слов'янськими посівами. Руси мають рабів слов'ян» [2, с. 47-48].

3 вище вказаного джерела стає зрозуміло, що торгівля була одним із головних занять русів, тому що самі руси не займались сільським господарством, а все, що їм було потрібно, вони забирали в слов'ян.

У роботі Ібн-Русте «Дорога цінностей» повторюється, що в русів немає майна, крім меча, нічого вони в спадок не отримують, і що едине їхнє заняття - це торгівля» [2, с. 45]. Автор констатує, що руси здійснюють на слов'ян напади з кораблів, захоплюють їх в полон і відвозять до Хозарану й Булкару, де їх і продають [3, с. 397].

У тексті «Худуд ал-Алам» про країну русів та їх міста зазначено, що руси платили десять відсотків не тільки за торгівлю своєму царю, але й десять відсотків зі здобичі. Руси були нахальні, схильні до сварок і войовничі. Вони воюють із всіма сусідами й перемагають їх. Серед русів є слов'яни, які шиють їм одежу [3, с. 339]. 
Текст про русів із твору Мутаххара ібн Тахіра ал-Мукаддасі «Кітаб ал-бад ва-т-таріх» повідомляє, що в русів немає ні пашен, ні скота. Вони нападають на землі слов'ян, грабують їх і забирають у полон [3, с. 398]. У тексті про русів із твору Шафар аз-Замана Тахіра ал-Марвазі «Табаі ал-хайава» йдеться про те, що руси - сильний і могутній народ. Вони здійснювали далекі походи на кораблях у Хозарське море й нападали на хозар і захоплювали товари [3, с. 400].

Ал-Істахрі вказує на те, що руси торгують із хозарами, візантійцями, болгарами й що візантійці платять їм данину [3, с. 412]. Отже, крім прибутків від розбою та торгівлі руси збирали данину.

Руси платили податки своєму царю (хакану). Через те, що вони жили коштом розбою та торгівлі, саме із цієї діяльності вони мусили сплачувати $1 / 10$ частину. Руси не займались ні сільським господарством, ні скотарством. Інформації про те, що руси займались ремісництвом, в арабів теж немає. У спадок від батька син теж нічого не міг отримати. Основним джерелом існування в руса залишався розбій і торгівля, без чого він існувати не міг. Отже, усі руси мали платити цареві, щоб займатись своєю діяльністю.

Араби розкрили інформацію і про сплату слов'янами податків. У тексті Ібн-Русте (Дорога цінностей) повідомляється про царя слов'ян, який кожного року об'їжджає своїх підлеглих. Якщо в когось із них є дочка, то він бере з неї одне плаття в рік. Якщо в підлеглого царя є син, то цар бере теж одне плаття в рік. Якщо в когось взагалі немає дітей, то плаття береться 3 жінки або служниці [4, с. 47]. Слов'янський цар брав податки 3 кожної сім'ї, де були діти, жінка або рабині.

Підходи до оподаткування в русів і в слов'ян були різні. Це можна пояснити різними економічними моделями. У русів і слов'ян згідно з арабськими джерелами були різні джерела доходів. Руси брали податок із торгівлі, що вказувало на велику роль комерції в житті русів. Сплата податків залежала від доходів руса, але разом із тим був фіксований процент від суми, що не давало владі зловживати й брати понад десять процентів від торговельних доходів і розбою.

Слов'яни ж займались землеробством і тваринництвом, і цар обкладав їх податками незалежно від доходу. Їх податки стосувались членів сім'ї. Для того, щоб зібрати податки, слов'янському царю потрібно було б здійснювати кожного року об’їзд територій.

Хакану русів для того, щоб зібрати податки зі свої підлеглих, потрібно було насамперед тримати під контролем місця здійснення торговельних операцій, через які йшов торговельний транзит, i кордони, через які йшла здобич. Хакану досить було контролювати ключові місця на кордонах. А через те, що руси здійснювали походи на кораблях, то контроль за річками давав можливість хакану перевіряти всіх, хто ними пропливає $[2$, c. 45$]$. Тут важливе місце має саме Дніпро й місто Київ. Саме Київ дає можливість перевіряти основний торговельний річковий транзит, що йшов у Візантію, Хозарію, Болгарію. Отже, всі руси, які хотіли займатись торгівлею з вище названими країнами, мусили заплатити хакану десять відсотків, тому що останній контролював ключові торговельні пункти. Звісно, ми припускаємо, що в русів була розроблена система збору данини в підкорених народів, але араби вказали тільки про наявність у русів данників. А як здійснювався процес збирання та які мали б бути обсяги сплати данини, в арабських джерелах не зазначено.

Як же за літописними джерелами данина платилась до приходу Рюрика?

У Холмогорському літописі вказується, що поляни, сіверяни, в'ятичі платили «по беле вереце от дима" хозарам. Чудь, словени, весь, кривичі платили данину варягам [5, с. 13]. На відміну від південних земель кількість данини, яку мали платити варягам, не називається. Джерело не вказує розмір данини, яку мали платити древляни й сіверяни Олегу після захоплення ним Києва.

Тверський літопис на відміну від попереднього вказав, що варягам данину платили чудь, словени, меря кривичі в розмірі «от мужа «по беле веверіце». Хозарам її платили поляни, сіверяни, в'ятичі «по беле векшице от дима» [6, с. 29]. Якщо взяти за основу сплату данини хозарам і варягам, то їх відмінність в тому, що на півночі податок брався з людини, а на півдні - 3 нерухомості або 3 основного засобу виробництва (плуга).

Наступний період нашого дослідження щодо сплати податків буде стосуватися Рюриків до прийняття християнства. Що собою являє данина? Данина, на думку B.Є. Курі, є ціною переможених, щоб відкупитися від рабства [7, с. 125]. Ми вважаємо, що данина - ширше поняття як довгострокова контрибуція підкорених народів.

Джерельною базою нам будуть слугувати руські літописи й візантійські джерела. Олег, зайнявши Київ, об'явив його центром Київської Русі. Оскільки Київ став столицею, то саме на ньому замкнулась уся система збору данини. Олег зобов'язав її платити слов'янам, кривичам і мерям. Новгород мав платити варягам, які були під рукою князя Олега, 300 гривень на рік $[8$, с. 13].

Олег замкнув систему сплати податків навколо Києва, а не Новгорода. Цікаво те, що літописець, перераховуючи племена, які мали платити податки, вказав на слов'ян. Слід з'ясувати: слов'ян сприймали як народ у цілому, тобто всі племена, які відносили до слов'ян, чи як окреме слов'янське плем'я ільменських словен. Проаналізуємо етнічне походження племен. 3 даних літопису, з трьох перерахованих народів меря не належали 
до слов'ян. Кривичі, навпаки, класифікувались саме як слов'яни [9, с. 347]. Під час аналізу джерела ми дійшли висновку, що, якби слов'ян класифікували не як племінний союз, а як народ, то кривичів би не згадали, тому що й ільменські словени, і кривичі є слов'янами. Ми вважаємо, що літописець перераховував саме племінні союзи. На основі проведеного аналізу літопису ми можемо вважати, що Новгород мав платити окрему данину в розмірі 300 гривень. Ільменські словени платили свій податок, а Новгород платив свій. Олег висунув податкові зобов'язання не жителям міста, де кожен мав стати індивідуальним суб'єктом відносин і платити данину, а місту в цілому, яке своєю чергою було центром управління землею. Податок встановлювався не з кількості прибутку, як у русів, і не з кількості людей та їх сімейного стану, як зазначалось нами вище й притаманно було до приходу Рюрика до слов'ян, з арабських джерел [10, с. 14]. За основу Олег взяв необхідну суму для утримання варязької дружини. Жителі міста самі мали б виробити систему збору цієї суми.

Не племінна община ільменських слов'ян, а місто стає суб'єктом зобов'язання. Саме Новгород гарантуе сплату коштів на утримання війська. Місто мало самоорганізуватися своїми власними зусиллями, виконати взяті на себе зобов'язання, зібравши вказану суму, і передати князю гроші для забезпечення миру. Звісно, потрібно дослідити, чи місто платило варягам, чи сам князь, якому місто передавало кошти. Якщо варягам платило місто, воно мало б влив на керівництво їхніми діями. Навряд чи саме Олег платив кошти, тому що він перебував в Києві. Ми припускаємо, що він делегував ці функції Новгороду. Не слід забувати, що Рюрика призвали підтримувати мир у землях ільменських слов'ян, а Олег усі основні військові сили зосередив на півдні Русі, де здійснював активну експансію. Це своєю чергою сприяло загрозі від набігів скандинавів через ослаблення військової присутності русів у регіоні. Найняті за 300 гривень найманці розв'язували зазначену проблему. Новгород отримав на постійній основі професійних вояків, на утримання яких і платив 300 гривень. Ці дії забезпечували підтримку миру в регіоні.

Наступним етапом нашого дослідження є система збору данини в племінних союзів півдня.

У тексті Супрасльського списку вказується, що древлянам потрібно було сплачувати по чорній куниці [11, с. 5]. Літописний звід 1497 року повідомляє про те, що Олег встановив данину древлянам і сіверянам, але в тексті літопису не вказано, як її мали платити [12, с. 5]. Володимирський літописець вказав, що сіверяни мали розірвати данницькі зобов'язання, які були встановлені хозарами, і почати платити легку данину русам. Про розмір легкої данини автор джерела не повідомив
[6, с. 15]. Щоб з'ясувати їі розмір, ми проаналізували текст Типографського літопису й простежили, що сплата однієї куни в рік класифікувалася джерелом як легка данина [13, с. 8]. У Софіївському літописі вказано, що древляни й сіверяни мали сплачувати по чорній куні [14, с. 89]. Ніконовський літопис теж підтверджує інформацію [15, с. 15]. У тексті Радзивілівського літопису вказано, що Олег наказав радимичам платити данину русам, а не хозарам. Радимичі мали платити таку ж данину, яку вони платили до цього хозарам, а саме по «щълоягу» [16, с. 18]. Літопис повідомляе про те, що Олег наказав сіверянам, древлянам i хозарам платити по одній куні від людини раз на рік [17, с. 18]. У літописах вказується про те, що Олег пішов на древлян і сіверів, одержав перемогу й встановив данину в розмірі чорної куни, а в наступний рік здійснив похід на сіверян і встановив їм легку дань [6, с. 33-34; 18, с. 9]. Джерело цікаве тим, що вказує про існування сіверів. Отже, з'являється новий племінний територіально-родовий регіон, в якому русам платили данину.

В.Н. Татіщев указав, що у 833 році Олег організував похід проти древлян та, отримавши перемогу, встановив їм дань у розмірі однієї шкури чорної куниці від диму [10, с. 14]. Олег у такому випадку встановив сплату данини 3 дому, тобто господарства, слов'янської сім'ї, яка там проживала в будівлі. Сім'я мала б від свого господарства сплатити данину в розмірі однієї чорної лисиці, і наявність кількості мешканців (дітей, жінок, рабинь) та їі прибуток не впливали на розмір данини.

у 884 році Олег підкорив сіверян і наказав їм не платити данину хозарам, а платити йому. Щодо кількості, то сіверяни мали платити русам легку данину [10, с. 14].

Наступними данниками Олега стали у 885 році радимичі. Він звернувся до радимичів і вказав їм, як і сіверянам, не платити данини хозарам, а заплатити Києві. В.Н. Татіщев указав, що радимичі за домовленістю з Олегом повинні були платити шлягу від плуга [10, с. 15].

Кількість данини мала бути того ж розміру, яку радимичі платили хозарам [10, с. 15]. 3 вище вказаного складається думка, що в русів і хозарів діяла однакова система збору данини. Можливо, що руси в такому випадку й брали за основу саме хозарську модель.

Д.Г. Черник, досліджуючи сплату данини, пояснив цей процес як початок зародження прямого оподаткування [19, с. 12-13]. М.М. Шевердін на підставі своїх досліджень теж дійшов висновку, що первинною формою прямого податку була саме данина, яка платилась у формі натуральної повинності [20, с. 123].

В.Н. Татіщев повідомляє, що в древлян, як і в радимичів, система збору данини прив'язувалась не до окремої фізичної особи. У древлян 
обкладався дим (будинок, господарство), а в радимичів данина відштовхувалась не від диму, в якому проживала й працювала родина, а від основного знаряддя праці, на базі якого й трималось господарство, а саме плуга. Можна припустити, що в древлян не досить було розвинуте сільське господарство, і тому дань було недоречно прикріпляти до плуга. Тому древляни залежали від житлового будинку, в якому проживала родина. Але події війни княгині Ольги проти древлян суперечать зазначеній гіпотезі. Під час осади Коростиня Ольга аргументувала необхідність здачі міста тим, що древляни не могли працювати на полях [10, с. 31] Отже, ймовірно, у кривичів плуг класифікувався не тільки як знаряддя праці, а і як господарська одиниця.

Порівнявши літописні дані з роботою В.Н. Татіщева, ми виявили, що інформація щодо оподаткування древлян, сіверян і радимичів суперечить одна одній. 3'ясуємо, чи згадувалися в пізніший час у літописах схожі умови збирання данини, про які згадував В.Н. Татіщев. У Вологодсько-Пермському літописі повідомляється, що Великий князь Святослав Ігорович наказав в'ятичам платити «по щьлягу від рала» [21, с. 19]. Така інформація вказує на те, що в Київській Русі все ж застосовувався такий спосіб збирання данини, хоч i згаданий в інший час.

Ми вважаємо, що данина має ширше поняття, ніж контрибуція.

В.Н. Татіщев сам указав, що після захоплення Олегом Києва була встановлена данина на слов'ян (ільменські слов'яни), русів, кривичів, меря [10, с. 14]. У Лаврентіївському літописі з перерахованих вище данників указується, що разом 3 Олегом на Київ виступили слов'яни (ільменські слов'яни) і кривичі й меря [22, с. 10]. Крім цього, саме слов'яни й кривичі й меря запросили Рюрика на князювання [15, с. 10]. Рюрик прийшов добровільно, й меря теж підпорядковувались йому [10, с. 12-13]. Тобто ні Рюрик, ні Олег не захоплював ці племена, але останній встановив їм данину. Тому не обов' язково сплата данини пов' язана з примусом і поразкою або добровільною капітуляцією.

За правління Ігоря відбулась криза в системі збору данини. Наприкінці правління Великого князя така система дала збій і вибухнула в древлянській землі. Князь, порушивши умови сплати данини, зібрав її декілька разів в один рік. Це призвело до конфлікту Ігоря з його данниками. У результаті цього князь Ігор Рюрикович був убитий древлянами [22, с. 23].

Чи можливо було в Київській Русі підняти данину своїм данникам? Відповідь на це питання дає Лаврентіївський літопис, згідно з яким у 914 році Ігор придушив повстання древлян і встановив їм данину більшу, ніж та, що була в минулому встановлена Олегом [22, с. 18].
Ці літописні дані вказують на можливість зміни данини шляхом її збільшення.

Коли князь Ігор у порушення попередніх домовленостей зібрав у древлян додаткову данину, останні не підіймали повстання проти нього й навіть заплатили додатково встановлену дань князю, і тільки ще одна спроба Ігоря змусила їх повстати й вбити князя [10, с. 28-29].

Дії князя з першого погляду здаються нелогічними. Саме в його діях і криється питання: чому стара система сплати данини дала збій і князь, порушуючи ним же встановлені правила, фактично обікрав древлян. Ми вважаємо, що причиною було банкрутство княжої казни й можливість військового бунту. Отже, з'ясуємо, які фактори вплинули на фінансові труднощі князівської казни.

Поява в 915 році печенігів і війни з ними теж мали б призвести до збільшення військових витрат [16, с. 24]. У 921 році був збудований великий флот [14, с. 97]. Пік фінансових втрат розпочався в 941 році. У цей рік Русь здійснила військовий похід на візантійців. Він закінчився катастрофою. Наступний військовий похід був організований Ігорем Рюриковичем у 944 році. Він був досить масштабний. Князь зібрав слов'ян, полян, кривичів, тиверців і найняв печенігів [10, с. 24]. Лаврентіївський літопис крім вище перерахованих вказує ще й варяг [22, с. 19]. Типографський літопис описує наявність у війську князя Ігоря і в'ятичів [6, с. 16]. Були найняті печеніги. Військо не дійшло до Константинополя, тому що князь Ігор замирився з візантійцями й отримав від них откуп [23, с. 21].

Русь із 941 по 944 рік не торгувала з Візантією. Це означає, що руси не мали можливості реалізовувати зібрану данину під час полюддя згідно з договором 907 року [24, с, 65-66].

Те, що з великокняжою казною були проблеми, вказують нам дані 944 року, коли власні воїни князя пропонували відправитись у землі древлян для збору данини. Воїни аргументували необхідність походу тим, що вони голі, без коней і без зброї на відміну від вояків Свенельда [22, с. 19]. 3 цього стає зрозумілим, що в князя не було коштів навіть на підтримку боєздатності своєї дружини. Ми можемо зробити висновок, що князь Ігор став неплатоспроможним. Військо фактично збунтувалось і вимагало від нього йти грабувати його данників, на що той погодився.

Причина кризи збору данини була у фінансовій прожерливості самого князя та його провалах у зовнішній політиці. Руська земля фізично не могла потягнути такі витрати, які відбулися за Ігоря. А тривале розірвання торговельних зв'язків із Візантією знівелювало полюддя, адже не було можливості вигідно реалізувати данину.

По смерті Ігоря, на думку багатьох вчених, відбувається податкова реформа княгині Ольги. 
Леонтій Войтович у своїй роботі «Княжа доба на Русі: Портрети еліт» вказав, що Ольга змінила систему збору данини на чітко регламентований державний податок. 3 часу її реформ замість «полюддя» 3 об'їзду княжої дружини, яка харчувалась із земель, по яких вона пересувалася, на заміну їм прийшли спеціальні чиновники - тіуни, визначалися і міста збору данини - погости [25, с. 217].

Але, як зазначалося вище, данина, яку встановлювали князі, була нормованою. Вона збиралася раз на рік і чітко була визначена в кожному племінному союзі. Залежно від розміру вона класифікувалась як легка й тяжка, залежно від оподаткованої одиниці бралася з диму, мужа, плуга.

Костянтин Багрянородний у своїй роботі «Про управління державою» в розділі 9-ому про русів, які приїжджають із Русі на однодревках у Константинополь, повідомив, що руси відправлялись на зиму в землі древлян, дреговичів, кривичів, сіверян та інших слов'ян, які платять данину, живуть там та ̈̈ збирають [2, с. 72-74]. Суть системи полягала в тому, що восени руси відправлялись у землі слов'ян для збирання данини, харчувалися теж там, а коли в річках рушився лід, відправлялися всі до Києва. Звідти руси відправлялися до Константинополя, де торгували максимум шість місяців, після чого поверталися додому й знову відправлялися в землі слов'ян збирати данину. Детальніше такий процес був досліджений у статті «Організація проведення полюддя в Київській Pyci» [26].

Слід зазначити, що арабські джерела теж повідомляють про русів, які відправляються в землі слов'ян, і поки там перебувають, утримуються їхнім коштом [2, с. 400].

Для збирання данини русам була необхідна ціла комплексна система, яка формувалась на базі централізаційних процесів, що відбувалися в русів. Війська русів були присутні кожного року в землях, які платили їм данину.

За даними Костянтина Багрянородного руси прибувають до Константинополя із зовнішньої Русі - Новгорода, де сидить син Ігоря Святослав, Смоленська, Любича, Чернігова, Вишгорода. Коли наступає листопад, руси виходять із Києва й відправляються в полюддя, у круговий об'їзд у слов'янські землі древлян, дреговичів, кривичів, сіверян та інших слов'ян, які платять данину русам. Там зимують та у квітні, коли сходить лід на річках, відправляються до Києва, а звідти до Константинополя. Слов'яни, кривичі, полочани будують для них кораблі [27, с. 71,72$]$.

Слід зауважити, що Костянтин Багрянородний вказав про існування Святослава й що той сидить у Новгороді [2, с. 72]. 3 цієї інформації можна дійти висновку, що полюддя, яке він описував, проводилось саме за княгині Ольги. Літописець указує на те, що після свого об’їзду княгиня повернулась до сина в Київ. Участь Святослава в битві з древлянами теж вказує на те, що він перебував у Києві $[10$, с. 32]. Ми дійшли думки, що Святослав опинився в Новгороді після «реформ Ольги», тому що до них він жив у Києві.

Ні в якому разі не слід вважати полюддя як не врегульоване обкрадання підкорених. Кривичі, через землі яких проходило полюддя, були одними із тих, хто добровільно запросив Рюрика до себе на князювання.

Е.А. Мельникова вважає, що данина доставлялася двома способами: в першому випадку київські князі самі іï доставляли, в другому - їм доставляли підлеглі племена самостійно $[28$, c. $84-85]$.

Отже, у русів була розроблена чітка система, де данина збиралася в містах, які виступали центрами збору данини, адже саме з них привозили сировину, яку, ймовірно, збирали руси під час полюддя. Головним шляхом транспортування виступали річки Дніпро й Десна. Транспорт (кораблі) вироблявся на півночі й потім доставлявся русам на продаж. Як тільки сходив із річок лід, данину відвозили з міст до Києва. Для об'єктивності слід наголосити, що джерело тільки вказує на те, що руси зимою відправляються зимувати до данників. Прямо ж про збирання данини джерело не вказує, а говориться про годування. Відомості про будівництво нових кораблів розкриває нам дуже важливий пазл загадки, як проводилось полюддя. Якщо руси відправлялися з Чернігова, Новгорода, Вишгорода, Любича, Смоленська тільки тоді, коли ламався лід на річках, то поверталися вони до Києва на кораблях.

Отже, руси відправлялися в полюддя на кораблях, і воно проходило по річках. Данина мала збиратися або восени, коли руси добиралися до міст, або весною. Ми вважаємо, що данина забиралась саме восени. Якби хтось не заплатив взимку, проти них можна було розвернути бойові дії та до весни заставити заплатити данину, тим самим не зірвавши доставку іï до Києва. Раз річки відігравали роль транспортного з'єднання, то й звозити iii мали до річок і там установлювати спеціальні пункти прийому данини (погости).

Розглянемо дії Ольги за її реформ. У книзі про життя княгині Ольги «О устроении земском» указується, що Ольга разом зі своїм сином і військом встановила в древлянській землі устави, уроки, ловища й повернулась у Київ. Коли пройшло літо, вона, залишивши сина в Києві, іде до Новограда й по річці Мстя починає установлювати погости, «і от лугов і ловітвъ дані і оброки, і по Днепру перевесища і села тако иже по Десне і по всей землі ловіща і знаменія і места і погости; и ізрядивши все сия и пересмотриъ своима очима возвратися въ Киев к сину» $[29$, с. 11]. 
Проаналізуємо дії княгині Ольги. Вона відправилась восени, тому що літо просиділа із сином у Києві. У полюддя теж відправлялись восени. Важливим повідомленням є дані про залишення в Полоцьку княгинею саней $[15$, с. 11]. Те, що Ольга ними користувалася, означає, що в Псков вона прибула на них. Отже, Ольга подорожувала взимку. Залишення саней може означати, що княгиня Ольга перебралася на інший вид транспорту, ймовірно, корабель. Княгиня зустріла зиму в землях ільменських словен і там зимувала. Псков був одним із торговельних річкових центрів. Костянтин Багрянородний назвав Новгород першим містом, з якого припливають купці. Можливо, він назвав це місто тому, що там сидів син Ігоря Святослав, а можливо, через те, що воно знаходилось найдальше з перерахованих до Києва. Новгород, Смоленськ, Любич, Чернігів, Вишгород - імператор точно назвав ці міста за їх розташуванням із півночі на південь.

Ольга встановлювала погости по річках. Мстя, Дніпро, Десна - це річкові шляхи до Києва з Новгорода, Смоленська, Любича, Чернігова, Вишгорода. Тобто ті міста, по яких проходило полюддя та де руси зимують. Вони ще до Ольги мали там встановити лови, погости, уроки й інше. Адже данина із цих регіонів почала платитись ще в період правління Олега, й із часом кількість данників тільки розширювалось. До того ж данина встановлювалась фіксована. А через те, що руси звозили ї̈ кораблями, то вони й встановлювали пункти збору саме по річкових маршрутах. I це все мало бути введено ще до правління княгині Ольги.

Ольга взимку відправилась у полюддя в ту пору й по маршруту, який описав Костянтин Багрянородний. Знаходилась там стільки, скільки руси під час полюддя. Проаналізуємо повідомлення імператора про находження в Новгороді Святослава. Ігор, перебуваючи в Києві разом зі своєю дружиною, не міг відправити свого єдиного малолітнього сина до Новгорода. Але це могла зробити вдова - княгиня Ольга, яка потребувала підтримки північних регіонів, i, ймовірно, саме Святослав був ціною їхньої покори.

Висновки. У русів і слов'ян до приходу Рюрика були різні по суті системи збору данини. Руський хакан брав із кожної фізичної особи фіксований процент із прибутку. Прибуток отримувався 3 розбою та торгівлі, які згідно з арабськими джерелами були основними джерелами існування русів. Слов'яни платили своєму царю із сина, дочки, рабині й жінки. Система податків у русів була основана на їх прибутках і залежала від військових походів і внутрішньої та зовнішньої торгівлі. Водночас у слов'ян надходження в казну залежало від кількості харчів. Адже чим більше їжі, тим більше можна прогодувати сімей, кожна з яких зобов'язана платити правителю слов'ян.
Прихід Рюрика й захоплення Києва Олегом дає можливість вибудувати нову систему данини, яка мала фіксований характер і накладалась на дим i плуг, тобто господарську одиницю. Сплата данини не залежала, як у минулому, ні від доходу, ні від складу сім'ї. Саме об'єднання Півдня та Півночі дало можливість створити глобальну систему збирання данини, відомості про яку нам надійшли від Костянтина Багрянородного та яка мала назву полюддя. Поняття данини в русів мало ширше значення, ніж контрибуція, і містило сплату як на добровільних засадах, так і примусових. I тому не слід вважати полюддя виключно як насилля над підкореними.

Система данини, яку встановив Олег, є продовженням хозарської системи сплати данини, а через те, що хозари здавали позиції, підлеглі їм слов'янські землі відходили русам. Руси своєю чергою не міняли данину, залишаючи ії такою, яка була в хозар.

Оподаткування з людини замінюється на сплату з господарської одиниці. Але в обох випадках, щоб зібрати данину, потрібно було створити систему, яка б дозволяла систематично її збирати з просторих земель, що й дало можливість створити полюддя. Ми вважаємо, що руси тільки контролювали сплату данини, її передачу, охорону й транспортування річками.

Необхідність збуту сировини, яка збиралась під час полюддя, привела до пошуків вигідних ринків її збуту. Таким головним ринком стала Вiзантія. Залежність системи полюддя від візантійських ринків призвела до фінансової катастрофи княжої казни за Ігоря Рюриковича під час його війни з Візантією. Спроба князя наповнити казну через грабування своїх данників стала причиною його вбивства й тимчасового руйнування системи збору данини в підлеглих племен. Це своєю чергою показало залежність полюддя від зовнішніх ринків.

Дії Ольги були спрямовані не на встановлення нової системи збору данини, а на запуск старої. Через те, що з Візантією був укладений новий договір, ринки Візантії знову ставали відкриті. Система полюддя, яку описав Костянтин Багрянородний, знову могла діяти. Ольга після смерті Ігоря підтверджувала старі домовленості й надавала гарантії, що зловживань із боку князівської влади не буде. Саме княгиня Ольга відновила систему збору данини, яка продовжила існувати до правління Святослава. Не могла Ольга провести реформу, тому що ії позиції були досить слабкі. На це вказує перебування іï сина в Новгороді.

\section{Jimepamypa}

1. Мельникова О.А. Древняя Русь в свете зарубежных источников. Москва : Логос, 2003. 609 с.

2. Фроянов И.Я. Сборник документов по истории СCCP IX-XIII ст. Москва : Высшая школа, 1970. 261 с. 
3. Новосельцев. А.П. Древнерусское государство и его международное значение. Москва : Наука, 1965. 476 с.

4. Грушевський М.С. Виїмки з джерел до історії України-Русі. Львів : Наукове товариство імені Шевченка, 1895. $143 \mathrm{c}$.

5. Полное Собрание Русскихъ Летописей. Холмогорская летопись. Ленинград : Наука, 1977. T. $34.250 \mathrm{c}$.

6. Полное Собрание Русскихъ Летописей. Летописный сборникъ, именуемый Тверской летописью. Санкт-Петербург : Типография Леонида Демиса Эдуарда Праца, 1863. Т. 15.505 с.

7. Кури В.Е. 0 прямых налогахв Древней. Казань : Юридический сборник, 1855. C. $105-152$.

8. Ипатиевская летопись. Санкт-Петербург : Печатная В. Головина Леонида, 1871. 616 с.

9. Полное Собрание Русскихъ Летописей. Русскій Хронографъ. Часть первая. Санкт-Петербург : Тип. М.А. Александрова, 1911. Т. 22.568 с.

10. Татищев В.Н. История Российская. Москва : Єрмак, 2005. Т. 2.735 с.

11. Полное Собрание Русскихъ Летописей. Западнорусскія летописи. Санкт-Петербург : Тип. М.А. Александрова, 1907. Т. 17. 648 с.

12. Полное Собрание Русскихъ Летописей. Летописный свод 1497. Летописный свод 1518. Москва, Ленинград : А.Н.СССР, 1962. Т. 28. 355 с.

13. Полное Собрание Русскихъ Летописей. Типографическая летопись. Санкт-Петербург: 2-я Государственная типография. Галерная 1, 1921. Т. $24.272 \mathrm{c}$.

14. Полное Собрание Русскихъ Летописей. Псковские Софиевские летописи. СанктПетербург : Типография Эдуарда Праца, 1851. T. 5.275 c.

15. Полное Собрание Русскихъ Летописей. Патриаршая или Никоновская летопись. Санкт-Петербург : Типография Эдуарда Праца, 1862. Т. 9. 256 с.

16. Полное Собрание Русскихъ Летописей. Радзивиловская летопись. Ленинград : Наука, 1989. Т. 38. $177 \mathrm{c.}$

17. Полное Собрание Русскихъ Летописей. Устюжские и вологодские летописи XVI - XVIII вв. Ленинград : Наука. 1982.T. 38. 228 с.

18. Полное Собрание Русскихъ Летописей. Симеоновская летопись. Санкт-Петербург : М.А. Александрова, 1913. Т. 18.283 с.

19. Черник Д.Г. Налоги в рыночной экономике. Москва : Финансы; ЮНИТИ, 1997. 384 с.

20. Шевердін М.М. Становлення та розвиток прямого оподаткування в Київській Русі (IX - XIII ст.). Науковий вісник Ужгородського національного університету. Серія ПРАВО. Випуск 22. Частина II. T 1. 2013. С. 120-123.

21. Полное Собрание Русскихъ Летописей. Вологодско-Пермская летопись. Москва : Наука, 1959. T. 26. $412 \mathrm{c}$.

22. Полное Собрание Русскихъ Летописей. Лаврентьевская и Троицкая летописи. Санкт-Петербург : Типография Эдуарда Праца, 1846. Т. 1.267 с.

23. Полное Собрание Русскихъ Летописей. Никаноровская летопись. Москва, Ленинград : А.Н. СССР, 1962. T. 27. $366 \mathrm{c.}$

24. Юшков С.В. Памятники Русского права. Москва : Госюриздат, 1952.287 с.

25. Войтович Л.В. Княжа доба на Русі: портрети еліти. Біла Церква : Видавець Олександр Пшонківський, 2006. 782 с.
26. Настюк А.А. Організація проведення полюддя в Київській Русі. Держава $i$ право : Збірник наукових праць: Юридичні і політичні науки. Вид-чий дім «Юридична книга». 2009. Вип. 43. С. 111-116.

27. Рыбаков Б.А. Мир истории. Москва : Молодая гвардия, 1984. 351с.

28. Мельникова Е.А. Древнерусское полюдье и древненорвежская вейцла. Древняя Русь. Вопросы медиевистики. 2017. № 3 (69). С. 84-85.

29. Полное Собрание Русскихъ Летописей. Книга степенная царского родословія. Санкт-Петербург : Тип. М.А. Александрова, 1908. T. 21. $342 \mathrm{c}$.

\section{Анотація}

Настюк А. А., Третяк С. М. Система збору данини до правління Святослава Ігоровича. - Стаття.

У статті нами досліджується виникнення та розвиток системи збору данини в Київській Русі. У нашій роботі ми проаналізували арабські джерела, в яких отримали дані про податкову систему в русів і слов'ян до приходу Рюрика. Нами було встановлено, що в русів і слов'ян були різні по суті системи збору данини. Якщо в русів система податків була основана на базі процентних відрахувань на користь хакана й залежала напряму від прибутків, розбою та торгівлі, то в слов'ян надходження в казну царя залежали від об'єму вироблених харчів, які своєю чергою впливали на кількість родин.

Наступним етапом нашого дослідження став період створення глобальної системи збору данини, яку візантійський імператор Костянтин Багрянородний назвав полюддя. Аналіз літописних джерел вказав, що система почалась формуватися після захоплення Олегом Києва. Ми дійшли висновку, що за основу системи сплати данини більшою мірою бралася хазарська модель.

Нами виявлено, що оподаткування з людини й сім’ї замінюється на сплату з господарської одиниці. Літописи вказують, що із самого початку формування системи сплати данини виплати були фіксовані й могли змінюватись тільки після спроб повстань із боку данників. Слід зазначити, що полюддя спонукало князівську владу шукати вигідні й великі центри збуту сировини. За вказаними критеріями таким центром стала Візантія.

Нами було встановлено, що залежність системи полюддя від візантійських ринків призвела до фінансової катастрофи в період правління Ігоря Рюриковича. Саме ця катастрофа, на нашу думку, і спричинила кризу в системі сплати данини. Ми вважаємо, що саме нестача коштів у казні руського князя через економічну блокаду Візантії й призвела до того, що були порушені данницькі відносини з древлянами.

y нашому досліджені ми дійшли висновку, що дії княгині Ольги були спрямовані не на встановлення нової системи збору данини, а на запуск старої, яка була зруйнована Ігорем Рюриковичем.

Ключові слова: данина, хакан, арабські джерела, полюддя, торговельні шляхи.

\section{Summary}

Nastyuk A. A., Tretiak S. M. The tribute system before Sviatoslav Ihorovich governing. - Article.

This article deals with the origin and development of the system of collecting tribute in Kievan Rus' before the reign of Sviatoslav Igorevich. We analyzed some Arab 
sources in which we obtained data on the tax system of Rus' and Slavs before the arrival of Rurik.

We found that the Rus' and the Slavs had essentially different systems of tribute collection. If the Russ tax system was based on interest deductions in favor of the hakan and depended directly on profits, robbery and trade, the Slavs revenues to the king's treasury depended on the amount of food produced, which, in turn, affected the number of families.

The next stage of our study was the period of creation of tax collection global system, which the Byzantine emperor Constantine the Bagrianorodnyi called "polyudya". An analysis of chronicle sources indicated that the system began to take shape after Oleg had taken over Kyiv. We came to the conclusion that the Khazar model was mostly based on the system of paying tribute.

We've found that individual and family taxation is replaced by a unit tax. The chronicles indicate that from the very beginning of the formation of the tribute system, payments were fixed and could change only after attempts at uprisings by the tributaries. It should be noted that the people prompted the princely power to look for profitable and large centers for the sale of raw materials. According to these criteria, Byzantium became such a center.

We found out that the dependence of the human system on the Byzantine markets led to a financial catastrophe during the reign of Igor Rurikovich. It is just the catastrophe, in our opinion, that caused the crisis in the tax system. We believe that it was the lack of funds in the treasury of the Rus Prince due to the economic blockade of Byzantium and led to the fact that the tribute relations with the Drevlians were broken.

In our study, we came to the conclusion that the actions of Princess Olga were not aimed at establishing a new system of tax collection, but to launch the old one, which was destroyed by Igor Rurikovich.

Key words: tribute, hakan, Arab sources, polyudya, trade routes. 